\title{
Assessing the Effects of Community Based Organizations' Activities on Poverty Alleviation in Mwatate Division, Kenya
}

\author{
Gertrude Chanya Chombo * \\ Q-Train Consulting, \\ PO box 17713 - 00500, Nairobi, Kenya \\ Professor David M. Minja \\ Department of Public Policy and Administration, Kenyatta University, Kenya \\ PO box 184 - 00200 City Square, Nairobi, Kenya
}

\begin{abstract}
Poverty is a global, national and community issue. Mwatate Division in Taita Taveta County, Kenya is one such area that has been faced with persistent poverty. This is despite the existence of 600 Community Based Organizations (CBOs) in the area. This prompted this study of assessing the effect of the CBO's activities on poverty alleviation in the area. The main objective of the study was to determine the effect of the CBO's activities on poverty alleviation. It utilized the empowerment theory. According to this theory, poverty alleviation entails empowering the impoverished. The study, a descriptive survey, employed both descriptive and quantitative statistical methods. The population of the CBOs was 600 whilst the target population was 206, out of which a sample size of 100 was studied.Both primary and secondary data formed part of the study. The primary data was collected using structured and unstructured interviews which were conducted on the leaders of the sampled CBO's. A simple questionnaire was executed through face-to-face interviews with the respondents in order to gather data. The secondary source was both printed and electronic; was consulted through extensive desktop research. Other sources were Central Bureau of Statistics, Ministry of Gender and Social Development, National Council for CBO's, various research agencies and existing records of poverty in the area. The data was analyzed using descriptive statistics. The major findings indicated that the CBOs' activities did not impact on the poverty status in the area. It was recommended that the CBOs needed empowerment so as to be effective.
\end{abstract}

Keywords: Community Based Organizations, poverty, poverty alleviation, empowerment, Community Based Organizations' activities, Mwatate Division.

DOI: $10.7176 / \mathrm{JPID} / 53-05$

Publication date:March $31^{\text {st }} 2020$

\section{Introduction}

1.1 Background to the Study

Rural poverty is a major issue that has bedeviled Africa and Kenya in particular. The World Bank estimated that the number of people living in extreme poverty ( $\$ 1$ a day) was just under 1 Billion in 2004. Most of the poor are based in the rural area and majority of them are women and children. The International Monetary Fund (IMF) Country Report Number 05/11 released in January, 2005 (Kenya: Poverty Reduction Strategy Paper) indicates that three quarters of the poor live in rural areas while the majority of the urban poor live in slum and peri-urban settlements. Further, a study by the World bank report (2009), reveals that in Coast province, about 61 per cent of the rural people are poor, and poverty ranges from 13 per cent to 90 per cent across the 140 rural locations. It also indicates that poverty levels are on the rise in the province with headcount poverty having increased from 55 percent in 1997 to 59 percent in 2005/06. (http://siteresources.worldbank.org/INTPOVRES/Resources/4772271103229847256/ch3.pdf: 08.04.11). Poverty manifests in severe deprivation of basic needs such as health, education, food and water (The East Africa, 12 October 2009). Other poverty indicators are inability to access land, financial services and employment, low agricultural yields, inequality, poor infrastructure and communications, lack of markets and irregular sources of income (Kenya's Country Strategy Paper of 2008-2013).

As a result of a steady decline in economic performance during the last two decades, the level of poverty in Kenya is gradually increasing (Kenya's Country Strategy Paper of 2008-2013), especially in semi-arid and arid areas. Mwatate Division, being a semi-arid and arid land, is hence facing many challenges regarding community uplifting and poverty alleviation. It has therefore become imperative that a participatory development strategy is developed from which programmes, projects and various action plans would result in order to achieve the poverty eradication and provincial priorities regarding the level of poverty in the region. This study aimed to assess the effect of the Community Based Organizations' activities in poverty alleviation. This will in turn provide understanding of the level of community participation in poverty alleviation initiatives in the area.

The government alone cannot provide the needed economic development and human welfare packages to alleviate poverty. The involvement of the people directly or indirectly will hasten the speed of development (Tunrayo, 2009). Poverty alleviation is a prerequisite for a nation's development as it involves major 
transformation of the lower and middle class above the poverty level. He further says that "the poor performance of government in meeting the socioeconomic quests of citizens is one of the causes of the proliferation of CBOs in the new millennium." As such, the role of CBOs through which the people are involved in development becomes critical. It also brings to perspective the significance of the role and relevance of the CBOs in community development (Mulwa, 2010). He further states that, the CBOs are platforms and instruments of community empowerment. They are voluntary associations where people organize themselves together in order to mobilize the potential of their collective power (Mulwa, 2010:207). It is therefore the role and impact these CBOs have in poverty alleviation that this study sought to identify.

\subsection{Research Problem}

Poverty is not only a national issue but is a global issue and so the government as well as the communities in Kenya cannot overlook it. Failure to respond to it will impact negatively on the country's economy, poor ranking in terms of its Human Development Index (HDI), as well as its national image (Ferreira \& Ravallion, 2008). The continued dependence on the government and the poor implementation of development projects has led to failure of various development projects and low level development in the rural areas. As a result, there was a need to bridge the gap created by low level development in the rural communities. To address this need, strategies like the self- help approach to initiation, execution and maintenance of development projects is being used by the CBOs. In this approach the CBOs enlist the active involvement of the community members in project geared towards the development of their local area. In the mid-1990s there were an estimated 5-17 CBOs in every village, and an estimated 300,000 in rural Kenya. This shows the emergence of the CBOs and their penetration in the rural area where poverty generally lies (Molyneux, Hutchinson, Chuma, \& Gilson, 2007).

Mwatate division has continued to face challenges of poverty despite the general government initiatives and strategies on poverty alleviation that have been rolled out in the various parts of rural areas. As part of rural development strategies, the government has come up with various plans to address poverty in the rural areas especially the arid and semi-arid lands (ASAL) which include Mwatate. Despite a total of 600 existing CBOs in the area as indicated by the Ministry of Gender, Children and Social Development (2011), poverty continues to be a challenge. There were inadequate basic social and economic services such as, schools, hospitals infrastructure and financial institutions. The people of Mwatate still lacked access to basic needs such as food, water and shelter.

According to the UNDP report on Human Development (2009), Kenya is categorized among countries with low human development. It attained a human development index (HDI) of 0.541 and Gini index of 47.7, which gives it a ranking of 147 out of 182 countries (UNDP. 2010. Human Development Report). Over the past decade, Mwatate has not witnessed any significant economic growth or downward trend in poverty. In this division, productive land is limited. Most people cannot afford the type of irrigation infrastructure required to cultivate in such areas (Taita Taveta District Annual Report, 2007-2008).

The Kenya Rural Development Strategy (KRDS) as well as the Strategy for Revitalizing Agriculture (RSA; 2004) recognize the role of participatory rural development and the need to devolve additional responsibilities to local authorities and communities. Throughout the country, the need to improve basic infrastructure and conserve the environment is seen as critical to development and improved agricultural production. One strategy has been to foster self-reliance and involve communities directly in their own development through the provision of financial and technical support direct to community based, demand driven and sustainable development initiatives that reduce poverty and contribute to better environmental management. In view of this, empowering communities in the identification, implementation and maintenance of projects contributes to improved socio economic services and amenities and also improved environmental management. Through the assessment of the activities of the CBOs in Mwatate in regard to poverty alleviation, the study also identified whether indeed the government strategies of community development by way of involving community participation in its development were bearing fruit.

Another issue of concern is the lack of specific poverty indicators for the area. This makes it difficult to measure the prevailing poverty levels. This has prompted the study so that such information is gathered from the respondents and in so doing shed light on the current poverty status of the area. The generalized statistics on poverty levels of the province indicate that poverty levels are still high. The provincial poverty ranking report indicated that Coast Province is among the poorest regions in the country (Kenya Government Poverty Index Report, 2010).

If participatory development contributes to community development, then the study will show whether the development activities through the CBOs in Mwatate are contributing to the local community development. The government also declares that there continues to be a need for capacity building in Small and Medium Enterprises (SMEs) and CBOs (Country Strategy Paper of 2008-2013). This being the case, it will be of interest to note whether the CBOs in Mwatate are benefiting from the capacity building strategies from the government. If they have benefited, has this had any influence on sustainable livelihood? 
1.3 Research objectives

1.3.1 The general objective

The general objective of the study was to determine the effect of CBO's activities on poverty alleviation in Mwatate Division.

\subsubsection{Specific objectives}

The study sought to achieve the following:

1. To identify the activities being carried out by CBOs in their quest to alleviate poverty

2. To establish the economic impact of CBO's on the local economy

3. To identify the relationship between the activities of the CBO's and poverty levels in the area.

4. To provide data relevant for the approaches to strengthen CBOs in attacking poverty

\subsection{Significance of the Study}

The findings of this study provided information that will influence the activities of the CBO's on poverty alleviation. The study also provided insight on the level of community involvement in self-help projects as a means of complementing government efforts. It also provided useful leads for further research on poverty alleviation and the CBO's in the community under study. In addition, the findings will be useful to the the micro and macro actors such as private donors and transnational communities who determine the developmental landscape in communities. Thus the study would be significant to the government, development agencies, civil society, the community under study and the academics.

\section{Methodology of the Study}

\subsection{Description of the area of study - Demographic and Socio-Economic Analysis}

Taita Taveta County, previously known as Taita Taveta District is one of the six counties within Coast Region in Kenya and is situated about $140 \mathrm{~km}$ northwest of Mombasa and $380 \mathrm{~km}$ southeast of Nairobi. It was recently divided into two, Taita and Taveta. The County covers an area of $17,128.3 \mathrm{~km}^{2}$ and is composed of four sub counties namely, Voi, Mwatate, Wundanyi and Taveta with a total number of twenty seven locations and seventy-seven sub locations. According to the population census of 2009, it is among the 10 least populated counties with a population of 284,657 out of which 145,334 are males and 284,657 are females (Kenya National Bureau of Statistics, 2010). Its population consists of the casual waged labour: sisal/farms. The district is classified as an arid and semi-arid (ASAL) district. The division consists of 7 locations and 21 sub locations and covers an area of 1,776.1 KM2 (Taita Taveta District Annual Report, 2007-2008).

\subsection{Research Design}

A research design may be described as a tool that assists the researcher to deal with the research question in the most logical or convincing way. It is a logical structure of collecting data. Before one does research, it is important to know the kind of evidence he/she will need. This will enable the researcher choose the most appropriate design to help collect data. According to Kothari (2004), it is the arrangement of conditions for collection and analysis of data in a manner that aims to combine relevance to the research purpose with economy in procedure. It therefore provides guidelines on the sequence of activities and how the activities will be carried out during research. The activities should facilitate the provision of data to address the research problem.

The study used a survey that gathered data and sought the description of phenomenon such as the activities of the CBOs and the effect of these activities on poverty alleviation in Mwatate. A survey is a procedure in which information is collected systematically about a set of cases such as people, organizations and objects. The cases or sample units were selected from a defined population and the aim was to construct a data set from which estimates could be made and conclusions reached about this population. The study, being a descriptive survey explained the activities of the CBO's and also established whether there was a relationship between these activities and poverty alleviation. As a descriptive study, it generally took raw data and summarized it in a useable form.

\subsection{Sampling Design}

The sampling frame was the list of all the CBOs in the Division. The population of study was $600 \mathrm{CBOs}$ which was sampled using random sampling to a sample size of $100 \mathrm{CBO}$ 's translating to a sample of size of $17 \%$ and 100 people that were interviewed. Out of the total 11 locations in the Division, 4 were selected through purposive sampling. The specific respondents were the leaders of the selected CBO's. This number of CBOs was chosen to represent population in the study area due to limited time and budget constraints. The sheer cost of data gathering pushes the student in the direction of some "convenience sample" (Sharp \& Howard, 1998).

\section{Findings and Discussions}


the women dominated the leadership of the CBOs and were more active than the men in the activities geared towards poverty alleviation in Mwatate. These observations were also been noted elsewhere as explained by Opare (2007). He states that "One critical observation is that women tend to dominate in CBOs concerned with members' economic welfare and are mainly focused on income-generating activities and mutual credit support [a tendency recognized elsewhere (Moser, 1998, p. 14)]. On the other hand, CBOs established to promote and manage development schemes in the community, such as School Management Committees and Water and Sanitation Committees had more male."

As far as membership was concerned, majority (59\%) of the CBOs had a total of between 0 and 24 members and $26 \%$ of them had between 25 and 49 members. On the other hand $9 \%$ had between 50 and 74 members, whilst only $1 \%$ had between 75 and 99 members and another $5 \%$ of the CBOs had over 100 members. Thus the CBOs have relatively manageable number of members. Mulwa, 2006 says that for the CBOs to be effective, they should be made up of small and manageable size of membership. Most of them were also concentrated in Mwatate Location, which is the urban part of the division and apparently houses the Divisional Headquarters and was soon to be the County Headquarters.

The findings also showed that the majority, which is $41.25 \%$ of the CBOs were over 6 years old, whilst $31.25 \%$ of them were between 3 and 5 years old. This period can be considered long term as stated by Chitere (1994), who implies that for a CBO to be effective, it should be long term. The findings on the capital bases of the CBOs also showed that that $96.25 \%$ of them had a capital base of below Kshs.249,000=. About $1.25 \%$ had capital base of between Kshs.250,000= and 499,000=; and another $1.25 \%$ had a capital base of between 500,000= and 999,999= and yet another $1.25 \%$ had over Kshs. 1 Million. This signifies financial incapacitation especially considering that $41.25 \%$ of them have been in existence for over 6 years and $31.25 \%$ of them have been in existence for a period of between 3 and 5 years old. The 'merry-go-round' and the members' contributions were the CBO's main source of funds. This meant that the CBOs basically relied on the little contributions from the members. This therefore led to the CBO's having very low capital bases.

The financial incapacity was attributed to lack of financial assistance from the government as explained by Chitere, (1999). He states that between the 1950s - 1965, the number of self-help projects in Kenya, for example schools, water and health care projects, were on the increase. However, by the end of the 1960's they started declining. One of the probable reasons for the decline was that many communities may not have received assistance from the government as expected (Chitere, 1999:116).

From the findings, the CBOs mainly depended on members' contributions to which the majority $(38.75 \%)$ stated as being their main source of income. Another $36.35 \%$ of the income was from the public through fund raising. It was also noted that the NGOs, the government and financial institutions only provided $11.25 \%, 10 \%$ and $3.75 \%$ of the income to the CBOs respectively. The CBOs had not accessed funds from financial institutions as a result of many reasons. These included inability to meet the requirements of these institutions, inadequate financial institutions leading to few options and also lack of information on the products offered by these financial institutions.

\subsection{The Economic Impact of the CBOs in Mwatate}

According to Mulwa (2010), the promotion of CBOs as instruments of community empowerment is a relatively new concept. He also noted that is despite there being some form of CBOs propagating community development by way of self-help community groups such as women and youth groups among others. However, these groups were seen as mere conduits of channeling 'development handouts'. This practice created paternalism where those endowed economically provide handouts to buy group loyalty. The impact of such efforts towards eradication of poverty has been miserably dismal or ineffective. These views explained the status of the CBOs in Mwatate Division in terms of their membership, magnitude of their socio economic activities as well as their capital base. In this regard, Johnson (as cited by Mulwa, 2010:207) and Chambers (1993), have lashed out at development agents, blaming the perpetuation of poverty more on their approaches than on the poor people themselves. Further, the government and the NGOs have also failed to address the issues that perpetuate poverty. This seemed to be the case even in the area studied as the support of the government and the NGOs in terms of providing funding and capacity building to the CBOs was minimal. The financial institutions had also not been an option for funding of these CBOs. This is critical in that if the CBOs are to be more effective, their partnership with these development agencies should be enhanced.

The CBOs are important vehicles for community development for many reasons. One of them is that they are fundamental to the success of and sustainability of the community-based projects. The CBOs approach enables the members in a community to benefit equitably from services and resources which would otherwise be concentrated on a few individuals in the community. For example CBOs accord an opportunity for extension workers to reach many people within a short period through the multiplier effect as it is cheaper to reach the individual farmers through their groups than through their individual farms.

Although the majority of the CBOs are engaged in community projects, these projects have not had impact 
on poverty alleviation. There had been no increase in the number of schools, hospitals or access to clean water. There had been no remarkable improvement in development policies and infrastructural facilities. On the other hand there was no notable increase in agricultural yields, markets, exploitation of natural resources or establishment of regular incomes among the community members. Whilst these were indicators of poverty levels, the study also revealed that the CBOs activities had not impacted the poverty levels and so poverty was still rife in that community.

The smaller percentage of the CBOs not engaged in community projects cited lack of finances, lack of understanding on development issues and inadequate mobilization as the major reasons for their lack of engagement in community projects.

The CBOs provide a forum where groups or communities decide and act on an issue which can best be solved through collective action. Other opportunities provided by the CBOs are collective learning and sharing experiences and confidence building. The process of empowerment is also only possible through CBOs as they consolidate collective capacity (Mulwa, 2010). This implies that empowerment is important for the effective function of the CBOs. From the study, the CBOs are in dire need for empowerment so as to be able to address the challenges they face when implementing their poverty alleviation strategies.

Politically, the CBOs provide a fertile ground for the consolidation of democratic civil society. Economically, they can be a base for launching economic empowerment of a community as members pull meager resources together for the common good. This had been demonstrated in the findings as most of the CBOs pulled their meager income through table banking and the merry-go-round concept and benefitted from this through loans and savings.

\subsection{The activities of the CBOs in Poverty Alleviation}

The CBOs are voluntary associations where people organize themselves together in order to mobilize the potential of their collective power. According to the study, the CBOs in Mwatate had done this through formation of a revolving fund popularly known as 'merry-go-round'. This formed their main source of income for both the individuals and the group. These findings also supported the view that the government's failure in supporting communities in development have led to the emergence of CBOs (Abegunde, 2009).

The data analysis showed that most of the CBO's activities were on service delivery. These services included buying communal utensils; capacity building/training; contribution/merry-go-round/fund raising/sales; farming/planting/beekeeping/livestock; caring for the vulnerable/orphans; real estate and; others such as selfemployment creation/empowerment/constructing bridges and community health. Out of these, the main activities were the provision of a platform for their members to engage in contributions or 'merry go round' which was a form of fund raising. These findings were in agreement with the views in the Community Development Journal, Vol. 43 No 1 January, 2008 pp $65-78$ which state that Community development practitioners are among the strongest proponents of citizen participation as an integral element of economic improvement and social change. Opare (2007) also shares the same views and states that though community-based organizations (CBOs) are small, informal organizations, indications are that they provide various services towards the development of rural communities and can be used as channels to route development information and other resources required to improve living conditions in rural communities. In this regard engaging in service delivery was one of the activities the CBOs used to address poverty. The CBOs in their various forms provide goods and services that enhance community development. People direct their efforts towards community development projects in order to improve their quality of life and reduce the effects of poverty. CBOs have a goal of embarking on sustainable projects that have a lasting future (Mulwa, 2008).

Apart from offering services to their members and the community, the CBOs also engaged in other activities. These have been outlined and majority of them are on environmental issues. Addressing environmental degradation issues is one of the ways of addressing poverty (Bansikiza 2007). This implied that the CBOs had discovered the value of environmental conservation and how that translated to poverty alleviation. Development is dynamic in nature and for it to be relevant it should respond to emerging or contemporary issues. This also explains the focus of the CBOs on environmental activities as these are the contemporary issues nationally, down to community levels. Hence, for the CBOs to remain relevant, they need to continue addressing the contemporary issues of development especially those relevant to their circumstances. In this case, environmental conservation is relevant in that the area is arid and semi-arid, receives low levels of rainfall annually. The planting of trees which is as a form of environmental conservation will in turn reduce poverty by way of increasing rain, reducing soil erosion and improving agricultural yields.

\subsection{The relationship between the activities of the CBOs and poverty levels in Mwatate}

Whilst the CBO's have strategies to address poverty, many of them are faced with the challenge of financial constraints when implementing these strategies. The financial constraints are mainly as a result of inability to access loans due to lack of collateral and general fear for loans. In this regard, they acknowledged that this had led 
to their ineffectiveness and general lack of impact on the local economy. The findings showed that the CBOs activities did not translate into an increase in schools; increase in hospitals; increase in access to clean water; increase in agricultural yields; improving on existing development policies; advanced infrastructural facilities and; leading to exploitation of the natural resources. These activities did not contribute much to the social and economic development of members and the community respectively. This is despite the majority of the CBOs engaging in community projects which were geared towards poverty alleviation. Nevertheless, they did not impact on poverty levels to a large extent except for improving communication, increasing markets and establishing of regular sources of income. They lacked the financial capacity to impact the local economy by way of increasing the number of schools, hospitals, agricultural yields, access to clean water, markets, improved communication, advanced infrastructural facilities or development policies. The existing community projects initiated by the CBO's also had not impacted on these phenomena and the poverty alleviation altogether. The projects were small scale and brought in little income to the members and the community at large. Hence, they did not lead the community to focus on the exploitation of their natural resources. As a result the poverty status remained unaffected by the activities of the CBO's.

These findings therefore indicated that there was little or no relationship between the activities of the CBOs and the poverty situation in Mwatate. The poverty situation remained unaffected by the CBOs activities; there was no change in number of schools and hospitals; access to clean water; agricultural yields; existing development policies; improved communication; increased markets; advanced infrastructural facilities; established regular sources of income; and exploitation of the natural resources.

\section{Suggestions for Further Research}

A similar research should be carried out in other divisions of the county so as to determine the extent to which the CBOs socio-economic activities have led to poverty alleviation. It will also establish whether there is a relationship between these socio-economic activities and the poverty levels in the division. There is also a need to carry out a research in the relevant government ministries, the ministry of Gender, Children and Social Development on the extent to which they are offering support to the CBOs in Mwatate Division. This will provide a forum for partnering with the $\mathrm{CBOs}$ and in so doing increase their effectiveness in community development, specifically poverty alleviation.

\section{Recommendations}

The study showed that whilst most CBOs engage in socio-economic activities, the same do not have much impact on the local economy. The challenge of financial constraints wss one of the reasons stated for the lack of poverty alleviation strategies. On the basis of these findings, a number of recommendations were made.

a) The government should be more active and visible to the CBOs. This will provide the CBOs with a forum to have their challenges addressed. It would also enable the government identify the reasons why the CBOs activities do not translate to a positive change in poverty levels.

b) There is need to build the capacity of the CBOs so as to engage in more valuable socio-economic activities. For example, capacity building should include training on book- keeping, proposal writing, project management, group dynamics, credit facilities and CBOs effectiveness.

c) Effective communication development demands that it be participatory. Hence, the CBOs should be encouraged to engage in more socio-economic activities that will increase their capital bases. These will in turn empower them to be more effective and so reduce poverty levels faster. The government should intervene in the various challenges faced by the CBOs. There is need for more interactive partnering.

\section{Conclusion}

The root causes of poverty and under development are complex. It is important that all members of the community participate. However, it is vital to acknowledge that there is no single path to development; neither can there be a particular universal formula on how to do development. Each country, county and each community must seek its own route to progress based on its own assets, taking into account its own history and prevailing circumstances. Participatory development embraces rights approach to development. Effective participation is one such intervention that will empower those involved as it activates a sense of collective responsibility which is a key ingredient of community development.

The CBOs started and supported with the right motives have the potential to become effective vehicles for community empowerment and forums with people's participation in decision making on matters that have to do with them and affect them. This is development for the people, by the people and with the people. They indeed create an opportunity where the weak, the poor and the powerless in the community get collective negotiating command and lobbying which are essential for influencing public policy in their favour. 


\section{References}

Abegunde, A. A.(2009). The role of community based organizations in economic development in Nigeria: The case of Oshogbo, Osun state, Nigeria. International NGO Journal Vol. 4 (5), 236-252.

Bowen, G. A. (2008). An analysis of citizen participation in anti-poverty programmes Community Development Journal, 43 (1) 65-78. Retrieved December 27, 2010 from http//www.oxfordjournals.org

Chambers, R. (1993). Rural development: putting the last first. Harlow: Pearson Longman Group.

Chitere, P. O. (1994). Community development. Nairobi: Gideon S. Were Press

Chitere, P. O. (1999). Community development: its conceptions and practice with emphasis on Africa. Nairobi: .Gideon S. Were Press.

Ferreira, F. H.G.; Ravallion, M. (2008). Global poverty and inequality : a review of the evidence (English). (World Bank Policy Research Working Paper No. 4623). Washington, DC: World Bank.

Government of Kenya (2003). Economic Recovery Strategy for Wealth and Employment Creation, 2003 - 2007. Nairobi: Government Printer.

Government of Kenya. (2008). Strategic plan 2008 - 2012, ministry of gender, children and social development. Nairobi: Government Printer.

Government of Kenya. (2008). Taita Taveta District annual report, 2007-2008. Nairobi: Government Printer.

Government of Kenya (2010). Poverty Index Report. Nairobi: Government Printer.

IMF (2005). Country Report No. 05/11 Kenya: Poverty Reduction Strategy Paper. Washington DC: IMF Publication Services.

Molyneux, C., Hutchinson, B., Chuma, J.,.\& Gilson, L. (2007). The role of community-based organizations in household ability to pay for health care in Kilifi district. Kenya Health Policy and Planning, 22 (6), 381-392. Retrieved Arpil 20, 2011 from http://heapol.oxfordjournals.org/content/22/6/381.full

Mulwa, F. W., (2008). Participatory monitoring and evaluation of community Projects Nairobi: Paulines Publications Africa.

Opare, S. (2007). Strengthening community-based organizations for the challenges of rural development. Community Development Journal, 42 (2), 251-264. Retrieved December 27, 2010 from http//www.oxfordjournals.org

Sharp, J. A., \& Howard, K. (1998). The Management of a student research project, $2^{\text {nd }}$ Edition. England: Gower Publishing Limited.

Tunrayo, A. T.,(2009). Effects of community based organizations activities on poverty alleviation in Yewa south local government area of Ogun state, Nigeria, Medwell Journals, Pakistan Journal of Social Sciences 6 (6), $343-349$.

UNDP. (2010). Human development report. New York: UNDP. Retrieved December 23, 2010 from

http://hdr.undp.org/sites/default/files/reports/270/hdr_2010_en_complete_reprint.pdf

World Bank (2009). Kenya poverty and inequality assessment executive summary and synthesis report, Report No. 44190-KE, Washington DC: World Bank

http://siteresources.worldbank.org/INTPOVRES/Resources/477227-1103229847256/ch3.pdf Accessed on April 8, 2011

Table 1. Area of District by Division

\begin{tabular}{lcll}
\hline Division & Area $(\mathbf{k m 2})$ & Locations & Sub Locations \\
\hline Wundanyi & 701.9 & 7 & 23 \\
Mwatate & $1,776.1$ & 7 & 21 \\
Voi & $2,972.0$ & 4 & 11 \\
Tausa & 318.9 & 3 & 8 \\
Mwambirwa & 43.3 & 1 & 3 \\
Taveta & 645.4 & 5 & 11 \\
Tsavo National Park & 10,680 & - & - \\
\hline Total & $\mathbf{1 7 , 1 8 2 . 3}$ & $\mathbf{2 7}$ & $\mathbf{7 7}$ \\
\hline
\end{tabular}

Source: District Statistics Office, Wundanyi, 2007 
Table 2: Sample Size

\begin{tabular}{lcl}
\hline Location & Population by CBOs & Sample Size \\
\hline Bomani & 2 & - \\
Bura & 99 & 26 \\
Mwachabo & 106 & - \\
Chawia & 51 & 13 \\
Kidaya/Ngerenyi & 56 & 14 \\
Kishamba & 51 & - \\
Mwakitau & 51 & - \\
Modambogho & 1 & - \\
Mwambirwa & 1 & - \\
Mwatate & 181 & 47 \\
Ronge' Juu & 1 & - \\
\hline Total & $\mathbf{6 0 0}$ & $\mathbf{1 0 0}$ \\
\hline
\end{tabular}

\section{Authors' Biography}

1. First A. Author: Ms. Gertrude C. Chombo is the Principal Consultant at Q-Train Consulting, Kenya. She passed her MBA - Strategic Management at University of Nairobi in 2007 and Master in Development Studies - Community Development at St. Paul's University, Kenya, 2011. She obtained her Bachelors in Education (Arts) from Kenyatta University, Kenya in 1994. She has research interest in Governance, Leadership, and Management among others. She is a current Ph.D student of Jomo Kenyatta University of Agriculture and Technology (JKUAT), Kenya in Governance and Leadership. She has a wealth of experience drawn from her over 20 years' of service in both private and public sector in Banking, Administration, Senior Management, Governance and Leadership.

2. Second Author: Prof. David M. Minja is an Associate Professor of Management, Department of Public Policy and Administration, Kenyatta University, Kenya. He has authored many books and research publications in governance and leadership. He has attended and presented articles in various conferences. He obtained his Doctorate in Organization Development \& Transformation, Cebu Doctors' University, Philippines in 2008, MA Leadership( Strategy \& Entrepreneurship) Pan Africa Christian University in collaboration with Trinity Western University Canada in 2006; an MBA ( Strategic Management), Newport University, California, USA in 1999; and a Bachelor of Arts (Economics and Business) Kenyatta University in 1989. 